\title{
4 Methods and Frameworks
}

\author{
The Tools to Assess Externalities
}

\author{
Harpinder Sandhu, Courtney Regan, Saiqa Perveen \\ and Vatsal Patel
}

\section{Introduction}

Demand for nutritious and sustainably grown food is increasing worldwide and is likely to grow in the future as 2 billion people are added to the existing human population by 2050 (Food and Agriculture Organization of the United Nations et al., 2019). Meeting this demand for food without impacting the environment and human health is a common goal for humanity and a priority for most governments (Sandhu et al., 2019, 2020; Sukhdev, 2018); The Economics of Ecosystems and Biodiversity, 2018). Yet to many observers, increasing production alone is not the solution; in fact, overproduction in the developed world is responsible for many of the negative impacts already felt. Industrial farming practices have reduced farm produce to commodities that are traded around the world. Global trade and mass movement of food as a commodity often results in highly distorted markets, volatility in food prices, and has caused massive changes in diets. Global trade often puts pressure on land use in many parts of the world and has been linked to deforestation and loss of biodiversity. All value chain stages of global food systems and many small scale agroecological systems are affected by global distortions and result in negative social and economic impacts in addition to the growing environmental impacts (The Economics of Ecosystems and Biodiversity, 2018).

In addition to the economic impacts, climate change poses one of the biggest risks to current food systems (Sandhu et al., 2012). Agricultural activities are not only affected by climate change but are also responsible for one-quarter of the total greenhouse gas emissions that contributes to global warming (Intergovernmental Panel on Climate Change, 2019). Farming and food systems can play an important role in reducing impacts on the natural environment, as agriculture occupies about $38 \%$ of Earth's terrestrial surface, consumes more than $70 \%$ of global freshwater, provides employment to more than 1 billion people, and produces food for all (Food and Agriculture Organisation of the United Nations et al., 2019). Farming and food system systems play a dominant role in shaping the landscapes, social, and economic aspects of communities and people around the world. However, the impacts of farming, both positive and negative, on people lives, health, social networks, and natural resources are not captured comprehensively (The Economics of 
Ecosystems and Biodiversity, 2018). Such an understanding is required in order to fix deficiencies in global and local food systems and farming practices.

Unaccounted impacts of agriculture and food systems, positive and negative, need to be captured comprehensively in order to respond to the global goals of operating within the planetary boundaries (Rockstrom et al., 2009). Operating within the nine planetary boundaries is essential to achieve the Sustainable Development Goals (SDGs) that include an end to poverty, zero hunger, good health and well-being, gender equality, clean water and sanitation, climate action, responsible consumption, life on land, etc. among others that are linked to agriculture (United Nations, 2015). In order to achieve the SDGs that are associated with agriculture, it is important to first examine the impacts of agricultural activities, then develop incentives to reduce them so that social, human, and natural capital in agriculture and food systems can be maintained and enhanced.

There are several approaches, methodologies, and tools that can be applied at the farm, landscape, and regional level and across food and agriculture value chains to understand the comprehensive costs and benefits of farming and food systems. One such approach that captures significant impacts and dependencies of agricultural and food systems on natural, social, and human capital is known as True Cost Accounting (TCA) (Aspenson, 2020; Lord, 2020).

This chapter describes the genesis of the TCA approach and its theoretical foundations that are established in the disciplines of Ecological Economics and Environmental Accounting. We then review and update recent scientific and economic literature in order to identify gaps in our current knowledge regarding TCA as applied to agriculture and food systems. We develop conceptual foundations of TCA in agriculture and food systems by defining key concepts, terms and methods, utility, and challenges in its application. We conclude by summarising current and ongoing work and initiatives that promote TCA.

\section{Genesis of TCA}

The discipline of economics clearly established the role of the market in economic development that also formed the basis of capitalism in the 18th century (Smith, 1776). However, by middle of 20th century, a greater realization of scarce natural resources and environmental pollution from industrial activities prompted expansion of neo-classical economics to include the impact of economic activities on the natural environment. The discipline of Environmental Economics included environmental pollution, whereas Natural Resource Economics started examining the supply and demand of natural resources (Daly and Farley, 2010). Both these disciplines encouraged Environmental Accounting, which is a sub-discipline of Accounting to account for any costs associated with the impacts of economic activities on natural resources. However, Environmental Accounting is limited in its scope, as it includes direct and indirect costs associated with the environment and does not fully capture impacts on environmental and societal health (Jasinski et al., 2015). 
At national and global scale, one widely used measure of wealth-gross domestic product (GDP) - uses principles of accounting to capture all goods and services produced in a given country annually. GDP is often criticized for not being inclusive in its reporting, as the significant impacts on nature and society are not part of national accounts (Costanza et al., 2009). Moreover, GDP does not adequately measure well-being.

By pushing the narrowly defined boundaries and by addressing the limitations of neo-classical Economics, including Environmental Economics and Natural Resource Economics, the discipline of Ecological Economics has established the broader foundations for capturing social, environmental, and economic sustainability by focusing on the global environmental limits and societal wellbeing (Daly and Farley, 2010). The principles of Ecological Economics provide the scientific and economic foundations for the initiatives and approaches such as TCA, which are inclusive and orientated towards societal well-being.

Based on these foundations, some initiatives have been undertaken over the past two decades to recognize and value the benefits that biodiversity provides to people, through including natural capital into national accounting process. One such global initiative led by the United Nations Environment Program known as the Millennium Ecosystem Assessment (Millennium Ecosystem Assessment, 2005) described the importance of natural resources by highlighting the role of ecosystem services as the life support system of Planet Earth. Another process led by the United Nations (UN), widely known as the System of Environmental-Economic Accounting, is developing tools to measure the contribution of the natural resources to the economy and the impact of the economy on these resources (United Nations, 2014). Inclusive Wealth Index is another such initiative by the UNEP to estimate the comprehensive wealth of countries by expanding the scope to include natural and human capital in addition to the produced capital.

The UN Environment Program has examined these issues through the Economics of Ecosystem Services and Biodiversity (TEEB) initiative. From 2014 to the present this initiative has delved into the development of scientific and economic foundations that capture the positive and negative impacts of agriculture and food systems through a project known as The Economics of Ecosystem Services and Biodiversity in Agriculture and Food systems (see Box 4.1, TEEBAgriFood; The Economics of Ecosystems and Biodiversity, 2018). It provides a comprehensive framework to analyze costs and benefits of global farming and food systems for appropriate policy responses. The TEEBAgriFood framework provides the direction to apply TCA in agriculture and food systems to evaluate food products, agricultural systems, diets, national accounts, and policy options.

\section{Box 4.1 The Economics of Ecosystems and Biodiversity}

\section{Salman Hussain}

The Economics of Ecosystems and Biodiversity (TEEB) and TEEBAgriFood feature prominently in the current chapter and indeed the current volume. 
This box aims to set out the origins of TEEB, the rationale for the TEEBAgriFood Evaluation Framework, and-perhaps most importantly-to provide clarity on two key misconceptions. First, TEEB is not a technical methodology; TEEB is first and foremost a stakeholder-led approach to mainstreaming the values of nature. It applies methods from, inter alia, environmental science, ecological economics, and social anthropology. Second, TEEB does not commoditize nature. Nature is not "priced," and it is not "for sale." Even though TEEBAgriFood is a TCA approach, and we seek where possible to monetize changes in capital stocks, in some cases it is neither appropriate nor possible to do so. And yet these changes that cannot be monetized remain relevant (and are included in TEEB) as they affect human welfare.

\section{The Origins of TEEB and TEEBAgriFood}

Inspired by the Stern Review on the Economics of Climate Change (Stern, 2007), which revealed the economic inconsistency of inaction with regard to climate change, Environment Ministers from the governments of the G8+5 countries agreed at a meeting in Potsdam, Germany in 2007 to "initiate the process of analysing the global economic benefit of biological diversity, the costs of the loss of biodiversity and the failure to take protective measures versus the costs of effective conservation". Aiming to address the economic invisibility of nature, TEEB emerged from that decision.

Although its genesis is linked to climate change, and indeed "carbon sequestration and storage" is part of the TEEB typology of ecosystem services, advocacy for better outcomes is very different for biodiversity compared with climate change. Biodiversity is the living fabric of our planet, including all its ecosystems, species, and genes, in all their quantity and diversity. There is no apex indicator-no equivalent to $\mathrm{ppm} \mathrm{CO}_{2}$-equivalent to rally around. From the start, TEEB had to consider how to deal with trade-offs, and this remains the case for TCA via TEEBAgriFood.

The remit of TEEB was to "correct the economic compass"-that is, the entire economy with its many industrial sectors. The agri-food sector is an apt choice for TEEB to focus on, given its impacts and dependencies on nature. The agri-food sector encompasses areas of economic activity beyond farm operations to include farm-related activities, such as processing, manufacturing, and transport. This sector is underpinned by complex ecological and climatic systems at local, regional, and global levels, and overlaying these natural systems are social systems. These systems (economic, ecological and climatic, and social) interface and interact with each other, and that is why TCA via TEEBAgriFood assesses the "eco-agri-food systems complex." 


\section{TEEBAgriFood as a Process}

The TEEBAgriFood Evaluation Framework is set out in this chapter. It can and is being applied by different stakeholders-governments, businesses, communities, and farmers - although we focus below on implementation by governments. Before the initiation of TEEBAgriFood, TEEB had developed and implemented a more generic Six-Step Approach for producing tailored economic assessments of ecosystems and biodiversity and supporting the mainstreaming of this information in policymaking on a country level included in a Guidance Manual ( www.teebweb.org/media/2013/10/TEEB_GuidanceManual_ 2013_1.0.pdf). The TEEB six-step approach is as valid for TEEB country studies unrelated to agri-food (such as the application to land reclamation options in Manilla Bay in the Philippines) as it is to TCATEEBAgriFood application incountry. When presenting TCA on a national level, it is a fair a priori assumption that senior-level policymakers in Ministries have any number of approaches that are "pitched" to them as novel solutions to issues at the environment/social/ economic interface. Among the important challenges in terms of deciding which TCA approach to adopt and which methods and data to input, it is important that TCA practitioners see the wood from the trees and are guided by its purpose and audience. The unique approaches of TCATEEBAgriFood (as set out in this chapter) address these challenges and are part of the "pitch" to decisionmakers.

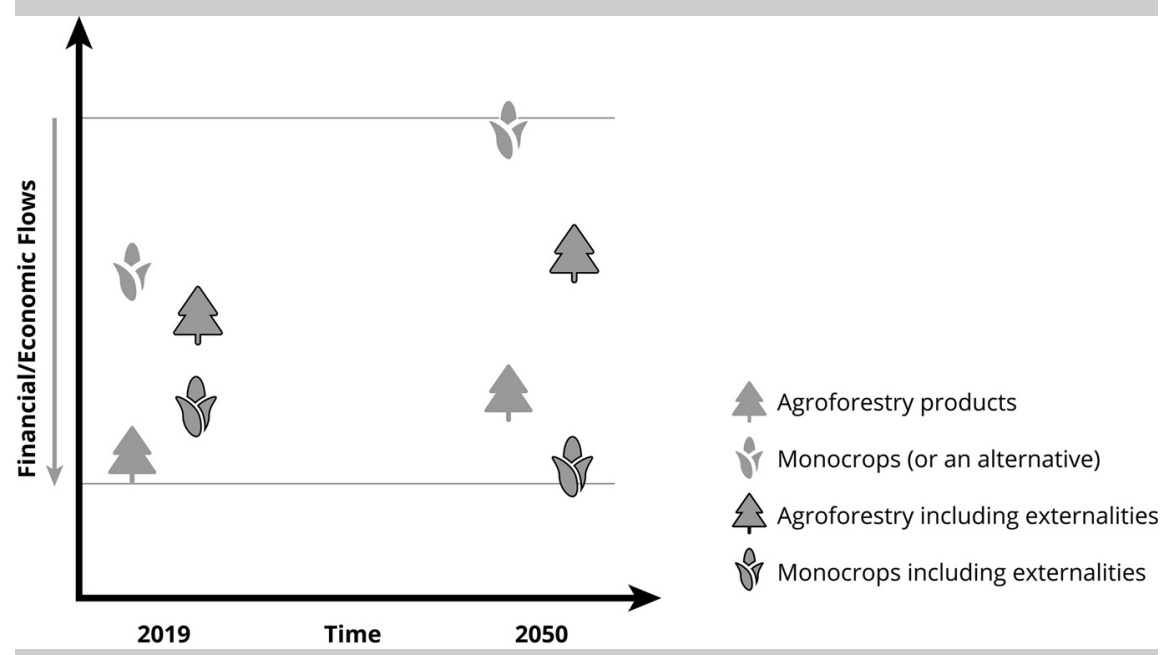

Figure 4.1 'Pitching' TEEBAgriFood to ministries: agroforestry vs monocrops.

The schematic in Figure 4.1 is the culmination of a series of slides used by the TEEB Office to highlight the TEEBAgriFood approach. The narrative that it summarizes is as follows: (i) if only financial flows that are marketed-that is, not including any externalities-are included in policy assessment then a 
government acting in the best interests of its citizens would pick monocrops over agroforestry today as the unoutlined maize icon (monocrops financial flows) is higher than the unoutlined tree icon (agroforestry financial flows) for 2019. However, if all positive and negative externalities and impacts are included (so the "economic" as opposed to "financial" flows), then the situation now changes -that is, in 2019 "agroforestry including externalities" is a better option than "monocrops including externalities."

If we look to 2050 projections, some modelling (or mere supposition) would show financial flows from monocropping even further outperforming agroforestry compared with 2019, but this is flawed. By 2050 monocropping will likely have depleted soil health and pushed ecosystems beyond planetary boundaries, causing declines in yield, and as a result, even these projected financial flows in 2050 likely overstate the superiority of monocropping. If we once again for 2050 (as we did for 2019) also include externalities, then agroforestry even further out-competes monocropping. In such TEEB "pitches," there is a need to validate this schematic representation above with evidence, and, depending on context, results from one of the TEEBAgriFood are presented, for example, the World Agroforestry Centre-led study for TEEBAgriFood (http://teebweb.org/agrifood/home/agroforestry).

This is just the start-to convince Ministries that TEEBAgriFood can be a useful approach compared with the myriad alternatives. From this, the TEEB Six-Step Approach is applied to determine via a stakeholder-driven participatory process what policy options TEEBAgriFood should be applied to. This process is critical. TCATEEBAgriFood should not be a technical analysis looking for a question; rather, it should be a policy question as formulated by an end user to which the TCATTEEBAgriFood framework is applied, adapted to the specific economic, political, social, and ecological context. If (and only if) stakeholders have been involved in and thus take ownership of this process from project inception will the results of the TCA TEEBAgriFood application have any chance of creating material change.

A part of the TEEB Six-Step Approach is to determine the constituency of "winners" and "losers" were a policy intervention to be adopted. This is important for two reasons: first, losers will tend to resist and/or block change, and in pragmatic terms it is important to be aware of this, as all decisions have a political dimension: just because the TCA reveals (say) that agroforestry improves net natural, social, human, and social capital compared with oil palm does not mean that it will be promoted; second, if the constituency of losers includes those in society that are poor with few or no alternative livelihood options then this is important vis-à-vis the changes that we advocate for.

The TEEB process has been successful. The interim TEEBAgriFood study for Indonesia contributed to cacao agroforestry being included in the 2020 Five Year Development Plan for Indonesia-the first time that it has been. TCA and TEEBAgriFood can make an impact, but only if considered as a process rather than just a technical methodology. 


\section{References}

Stern, N.H. (2007). The Economics of Climate Change: The Stern Review. Cambridge: Cambridge University Press. doi:10.1017/CBO9780511817434.'

\section{Conceptual Foundations of TCA in Agriculture and Food Systems}

Agriculture and food systems, being extremely diverse and complex, require an assessment approach that can capture all impacts and dependencies (The Economics of Ecosystems and Biodiversity, 2018). Unlike extractive industries, agriculture, and food systems include physical, human, and social inputs. The outcomes of current agriculture and food systems are increasingly linked to various chronic diseases such as cancers, obesity, pesticide poisoning, etc. Agriculture and food systems are also embedded in social systems (Pretty, 2003). Therefore, a transdisciplinary approach is required to estimate all costs and benefits of agriculture and food systems (Sandhu et al., 2019).

The TEEBAgriFood framework provides a conceptual basis of TCA (Figure 4.2). It extends our current understanding of estimating environmental accounts and includes social and human health impacts. It is based on a systems approach. All economic, biological, and social components of agriculture and food systems are part of the TCA method. Four forms of capitals that are associated with TCA in agriculture and food systems are described below (Table 4.1).

\section{Produced Capital}

Produced capital is based on the concept measured in the Inclusive Wealth Report by the UN University's International Human Dimensions Programme on Global Environmental Exchange and the United Nations Environment Programme (United Nations University - International Human Dimensions Programme on Global Environmental Exchange and United Nations Environment Programme, 2014) and defined by the TEEBAgriFood Report (The Economics of Ecosystems and Biodiversity, 2018). The stocks and flows associated with produced capital are measured by concepts and definitions of accounting standards at farm level, landscape level, and corporate level (processing), by using definitions from the System of National Accounts.

\section{Natural Capital}

Natural capital includes natural resources such as air, water, soil, and biodiversity associated with agriculture. Natural capital can be measured by using 


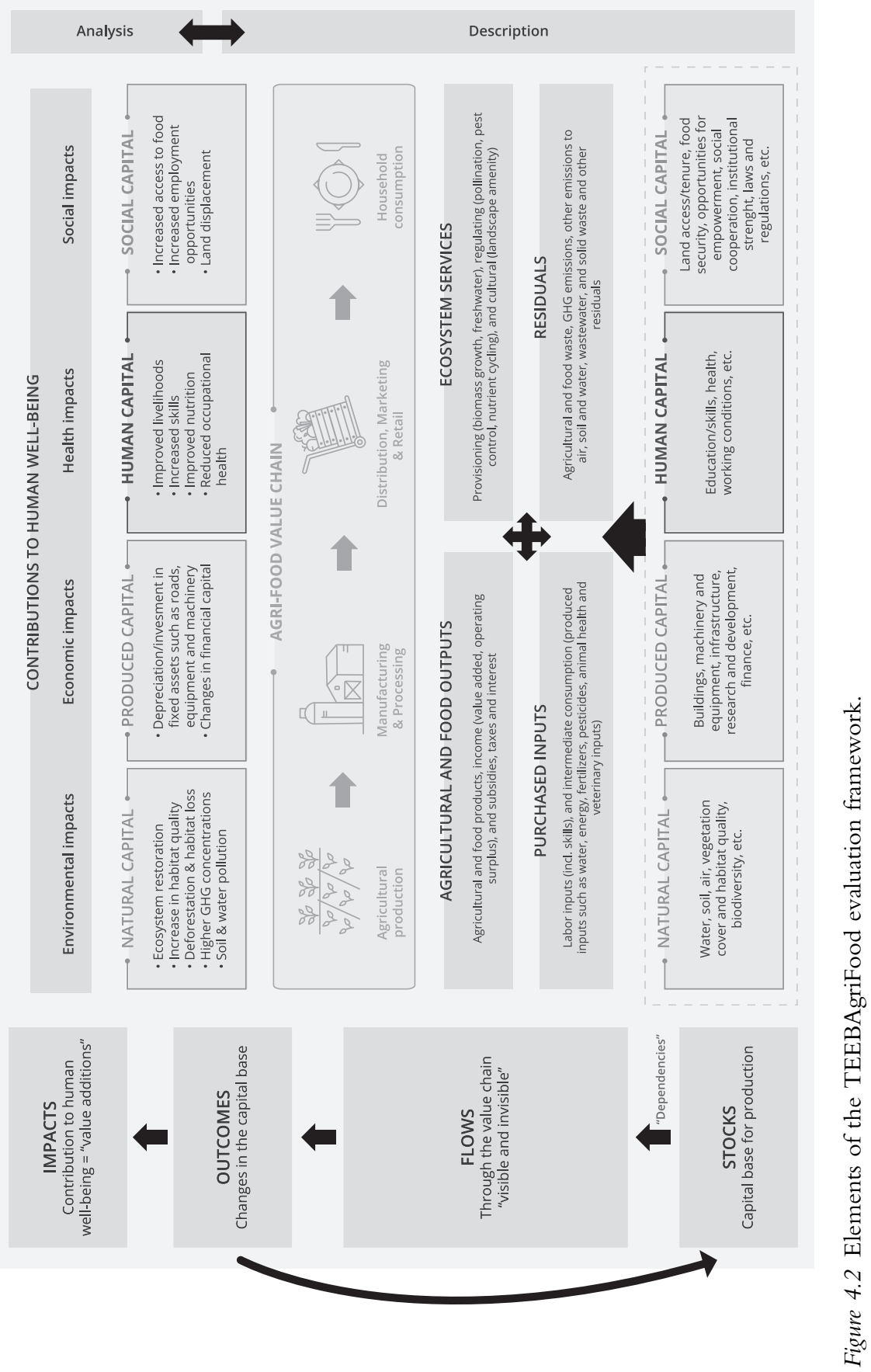


the United Nations System of Environmental-Economic Accounting (United Nations, 2014).

\section{Social Capital}

Social capital is defined as the features of social life, networks, norms, and trust that enable participants to act together more effectively to pursue shared objectives (Putnam, 1993; Sandhu et al., 2020; The Economics of Ecosystems and Biodiversity, 2018). Its four key features are relations of trust; reciprocity and exchanges; common rules, norms, and sanctions; and connectedness in networks and groups (Pretty, 2003).

\section{Human Capital}

Human capital comprises an individual's health, knowledge, skills, and motivation that are essential for productive work. It is based on the premise that individuals and society derive economic benefits from investments in people (Sandhu et al., 2020; Sweetland, 1996; The Economics of Ecosystems and Biodiversity, 2018).

\section{Utility of Environmental Accounting Approaches}

This section summarizes current environmental-accounting approaches that are being used to measure and understand the environmental impacts of different operations, as can and are being used in TCA. There are several approaches, methods, and models that are currently being used to capture environmental impacts of processes and products in various industries (Bebbington et al., 2001; Elkington, 1999; United Nations, 2014). Over the past several decades, Environmental Management Accounting (EMA) systems have been developed that use several approaches such as environmental cost accounting, full cost accounting, and environmental balanced scorecard (Bebbington et al., 2001, 2007; Jasch, 2003; Jasinski et al., 2015). These are summarized in Table 4.2.

\section{Application of TCA Approach}

The TCA approach can be used to identify benefits and costs associated with agriculture and food systems that are not captured in general accounting frameworks and tools. TCA includes all environmental, social, and health-related costs and benefits of agriculture and food systems. TCA often uses damage function approach (damage costs) and the cost of control approach (avoidance, restoration, abatement, and maintenance costs) to estimate the true cost of food production through the value chain, as demonstrated by the TEEBAgriFood framework. It can be used to:

- Develop sustainable agriculture and food systems by first understanding all externalities and then by reducing them;

- Develop sound policy responses for just agricultural and food policies; 
60 Sandhu, et al.

Table 4.1 Four Types of Capital, Stocks, and Flows Associated with Agriculture and Food Systems

\begin{tabular}{|c|c|c|}
\hline Capital & Stocks & Flows (+/-) \\
\hline Produced & $\begin{array}{l}\text { All manufactured/built capital such } \\
\text { as farm buildings, machines and } \\
\text { equipment, physical infrastructure } \\
\text { (roads, irrigation systems), proces- } \\
\text { sing plant, storage, warehouses, } \\
\text { retail stores etc; knowledge and } \\
\text { intellectual capital embedded in, for } \\
\text { example, seed development, fertili- } \\
\text { sers, agrochemicals, GM/hybrid } \\
\text { seed, etc.; and financial capital such } \\
\text { as farm loans, investment, insurance, } \\
\text { etc. }\end{array}$ & Rent, all inputs, output \\
\hline Natural & $\begin{array}{l}\text { Soil, water, biodiversity, } \\
\text { atmosphere }\end{array}$ & $\begin{array}{l}\text { Water runoff, aquifer recharge, local } \\
\text { climate regulation by carbon seques- } \\
\text { tration, regulation of atmospheric } \\
\text { chemical composition, soil erosion } \\
\text { control, role vegetative cover plays in } \\
\text { soil retention, nitrogen fixation, } \\
\text { nutrient cycling, biological control of } \\
\text { pests/diseases, greenhouse gas emis- } \\
\text { sions from farm, damage to water } \\
\text { resources, soil resources, ecosystems } \\
\text { and biodiversity, honey bee and } \\
\text { pollination losses and gains, loss of } \\
\text { beneficial predators by pesticides } \\
\text { application, biological control of pests } \\
\text { and diseases, fish kills owing to pesti- } \\
\text { cides, bird kills owing to pesticides }\end{array}$ \\
\hline Social & $\begin{array}{l}\text { Farming group networks, partner- } \\
\text { ships with research and develop- } \\
\text { ment, individual links, market } \\
\text { linkages }\end{array}$ & Loss of labour, small family farms \\
\hline Human & $\begin{array}{l}\text { Farmers knowledge, proficiency in } \\
\text { farm practices, use of software, } \\
\text { health, employment opportunities }\end{array}$ & $\begin{array}{l}\text { Loss of traditional knowledge, } \\
\text { impacts on health of farmers, } \\
\text { consumers }\end{array}$ \\
\hline
\end{tabular}

Note:

* Stocks of capitals are accumulated over time.

* Flows are processes over a period of time. Flows can be described in the form of ecosystem services, agricultural inputs and output, and any residual flows such as pollution and greenhouse gas emissions.

- Reduce impacts on natural resources and operate within the planetary boundaries;

- Justify better appreciation, valuation, and payments to farmers;

- Enable consumers to support food that is sustainably grown and has lower impacts; 
Table 4.2 Types of Accounting Approaches

\begin{tabular}{|c|c|c|c|}
\hline Approach & Definition & Costs & Reference \\
\hline Cost accounting & $\begin{array}{l}\text { Accounting for direct and in- } \\
\text { direct costs. }\end{array}$ & $\begin{array}{l}\text { Direct }+ \\
\text { Indirect costs }\end{array}$ & $\begin{array}{l}\text { United } \\
\text { Nations, } 1953\end{array}$ \\
\hline \multirow[t]{4}{*}{$\begin{array}{l}\text { Environmental } \\
\text { cost accounting }\end{array}$} & $\begin{array}{l}\text { The system of accounting } \\
\text { for estimating direct environ- } \\
\text { mental costs of a product } \\
\text { or a process. These costs include } \\
\text { fossil energy use, materials } \\
\text { obtained from nature, } \\
\text { wastewater and solid waste } \\
\text { that directly affects the } \\
\text { environment }\end{array}$ & $\begin{array}{l}\text { Internal } \\
(\text { Direct) }+ \\
\text { External } \\
\text { (Indirect) } \\
\text { costs }\end{array}$ & $\begin{array}{l}\text { Bebbington } \\
\text { et al., 2001; } \\
\text { Madu, 2001; } \\
\text { United } \\
\text { Nations et al., } \\
2014\end{array}$ \\
\hline & $\begin{array}{l}\text { Life cycle costing includes all } \\
\text { stages of the value chain. It } \\
\text { includes production, processing, } \\
\text { manufacturing, distribution, } \\
\text { consumption and recycling. This } \\
\text { approach is focused on the use } \\
\text { of resources and reflects both } \\
\text { internal and external costs. } \\
\text { Internal costs include cost of } \\
\text { materials, energy, labour, capital } \\
\text { etc., whereas external costs } \\
\text { include environmental impact of } \\
\text { the processes, cost of pollution, } \\
\text { cost of health-problems and } \\
\text { social costs. }\end{array}$ & & Howes, 2003 \\
\hline & $\begin{array}{l}\text { Activity based costing } \\
\text { includes the costs of each } \\
\text { activity that is required to pro- } \\
\text { duce a product. This approach } \\
\text { helps to divide environmental } \\
\text { costs (by products), composition } \\
\text { of the environmental costs } \\
\text { and strengthen the environmental } \\
\text { cost management of the } \\
\text { operations. }\end{array}$ & & $\begin{array}{l}\text { Almeida \& } \\
\text { Cunha, 2017; } \\
\text { Hoozee \& } \\
\text { Hansen, } 2018 .\end{array}$ \\
\hline & $\begin{array}{l}\text { Material flow costing measures } \\
\text { the flows and stocks of materials } \\
\text { in manufacturing. It produces } \\
\text { accounts in both physical and } \\
\text { monetary units. Material cost } \\
\text { accounting helps organizations to } \\
\text { improve their business efficiency } \\
\text { and reduce environmental } \\
\text { impacts. }\end{array}$ & & $\begin{array}{l}\text { Christ \& } \\
\text { Burritt, } 2015\end{array}$ \\
\hline
\end{tabular}


Table 4.2 (Cont.)

\begin{tabular}{|c|c|c|c|}
\hline Approach & Definition & Costs & Reference \\
\hline $\begin{array}{l}\text { Full cost } \\
\text { accounting }\end{array}$ & $\begin{array}{l}\text { A system that explicitly includes } \\
\text { all direct and indirect costs and } \\
\text { benefits of a transaction. Most of } \\
\text { the tools in EMA measure direct } \\
\text { costs of pollution, but full cost } \\
\text { accounting includes indirect costs } \\
\text { as well. These indirect costs and } \\
\text { benefits are incurred by the direct } \\
\text { beneficiaries or any third parties } \\
\text { involved in a transaction. It } \\
\text { includes conventional business } \\
\text { costs, environment costs and } \\
\text { social costs of products or services }\end{array}$ & $\begin{array}{l}\text { Internal } \\
\text { (Direct) }+ \\
\text { External } \\
\text { (Indirect) } \\
\text { costs }+ \text { Social } \\
\text { costs }\end{array}$ & $\begin{array}{l}\text { Bebbington } \\
\text { et al., 2001; } \\
\text { Elkington, } \\
\text { 1999; Gale \& } \\
\text { Stokoe, 2001; } \\
\text { Jasinski et al., } \\
2015\end{array}$ \\
\hline $\begin{array}{l}\text { Environmental } \\
\text { balanced } \\
\text { scorecards }\end{array}$ & $\begin{array}{l}\text { An accounting method to assess } \\
\text { social, economic, and environ- } \\
\text { mental performance of an organi- } \\
\text { zation. It includes both financial } \\
\text { and non-financial performance } \\
\text { and allows organizations to look } \\
\text { at their business from five per- } \\
\text { spectives; economic, social, inter- } \\
\text { nal business, learning, and growth } \\
\text { and environmental. }\end{array}$ & $\begin{array}{l}\text { Economic }+ \\
\text { Social }+ \\
\text { Learning and } \\
\text { growth + } \\
\text { Internal pro- } \\
\text { cess + Envir- } \\
\text { onmental }\end{array}$ & $\begin{array}{l}\text { Al-Zwyalif, } \\
\text { 2017; Kalender } \\
\text { and Vayvay, } \\
\text { 2016; Kaplan } \\
\text { and Norton, } \\
\text { 1992; Krivo- } \\
\text { kapić and } \\
\text { Jovanović, } \\
\text { 2009; Sandhu, } \\
\text { 2013; Sandhu } \\
\text { et al., 2014 }\end{array}$ \\
\hline
\end{tabular}

- Incentivise agricultural practices that are less detrimental to the environment and human health and to penalise those that have high impacts;

- Help better accounting of natural capitals in national accounts for further investment in their management;

- Protect traditional food systems;

- Enable integration of biodiversity into agricultural landscapes;

- Help achieve Sustainable Development Goals.

\section{Challenges in Applying TCA}

TCA is a more comprehensive and up to date approach that can be used from farm scale to national policy level. However, there are several limitations and challenges in the adoption of the tool that are further discussed here.

\section{Data Source and Collection}

One of the key challenges in applying TCA is data source and data collection. There are lots of data that are already available in scientific literature and in farm accounts that are very helpful in TCA analysis (Soil \& More Impacts and 
TMG Thinktank for Sustainability, 2020). However, a process to streamline data collection is required with some uniform standards at local, regional, and global scale. Working with farmers to share their farm accounts is also a nuanced process with many safeguards required.

\section{Complexities of Value Chains}

Agriculture products and food systems have extremely complex value chains, ranging from locally produced to locally consumed fresh food to global chains such as those for cereals, coffee, cocoa, cotton etc. Owing to these complexities, it becomes difficult to trace the entire chain from production to consumption to develop a comprehensive understanding of all positive and negative impacts. Even if the impacts are estimated for one stage of value chain, the response might not be sufficient to reduce overall impacts.

\section{Inclusion of Health and Social Impacts}

Impact assessments by business are mostly focused on improving the natural capital base for their businesses as a part of creating positive value for shareholders. Therefore, they focus on tracking and reducing carbon emissions, as this is the global focus as well. However, the impacts on biodiversity, water, oceans, health of their workers, health of consumers, etc. is rarely on the agenda of such impact assessments. A transdisciplinary approach is required to expand the scope from biophysical impact assessment to health and social impacts through the value chain.

\section{Target Audience}

TCA is a tool that can be useful for producers, supermarkets, agri-businesses, and governments. However, there are challenges in scoping each study based on its target audience. If farmers want to use it to correct their detrimental farming practices, then the scope is limited to farm scale. In contrast, if a supermarket wants to raise awareness of the food that they sell, they need to have a wider scope for applying TCA. At a governmental level, TCA needs to include policy assessment.

\section{Uniform Standards and Practices}

A lack of uniform international standards is one of the key challenges for TCA application in agriculture. There are several iterations and ways in which TCA approaches are being used. Some organizations are conveniently using it to create value for their organization and demonstrate positive values created by their operations, in terms of water as a capital stock, for example. Other organizations use it to start a conversation with prospective sustainability issues. A lack of international standards allow organizations to use and misuse TCA for their own advantage. Such practices can reduce the utility of TCA. 


\section{Incentives in Market and Policy}

Currently, some markets provide incentives to organic food with premium prices that are paid by consumers. Beside this there are no such incentives at farm, market, or national agricultural policies to apply TCA and to understand impacts.

\section{Consumer Awareness}

Consumers are not aware of all impacts of food systems. However, there is an increase in the number of consumers who demand full disclosure in how food is produced. TCA can help them to understand these impacts and then support food products that are less damaging. But there is a need to raise awareness amongst consumers about the utility of TCA as a comprehensive tool.

\section{Legal Framework}

A lack of policy at national and global level also means that there is no existing legal framework to advance the use and implementation of TCA through the value chain of each agriculture and food product.

\section{Conclusion}

TCA uses a systems approach, building on the existing environmental cost accounting framework. It extends its scope to include social, human, and health impacts in addition to environmental impacts in order to develop more sustainable agriculture and food systems. Development of a TCA approach is a first step in advancing methodology to analyze current systems to better understand and improve them. Further development of international standards followed by policy response through appropriate market incentives and national agriculture policies will help in the adoption of TCA applications more widely. This has the potential to assist the global community with operating agriculture and food systems within planetary boundaries and advancing the well-being of farming communities around the world.

Farming and food systems can be made more resilient to climate change. There are several ongoing initiatives that promote resilience to climate change and consider agricultural landscapes as multifunctional landscapes that provide multiple ecological, social, and community benefits. Transition to agroecological, regenerative, and circular agriculture are ongoing efforts in many parts of the world. This is a positive outcome of applying a TCA approach to identify and minimize the negative impacts of human, social, and natural capital in agriculture and food systems. Recognizing and measuring all positive and negative externalities by using TCA is not an end but a beginning towards more equitable and sustainable agriculture and food systems and the achievement of the well-being of society at large. 


\section{References}

Almeida, A., \& Cunha, J. (2017). The implementation of an Activity-Based Costing (ABC) system in a manufacturing company. Procedia Manufacturing, 13, 932-939. doi:10.1016/j.promfg.2017.09.162.

Al-Zwyalif, I. M. (2017). Using a Balanced Scorecard Approach to Measure Environmental Performance: A Proposed Model. International Journal of Economics and Finance, 9(8), 118-126. doi:10.5539/ijef.v9n8p118.

Aspenson, A. (2020). "True" Costs for Food System Reform: An Overview of True Cost Accounting Literature and Initiatives. Baltimore, MD: John Hopkins University. Available at: https://clf.jhsph.edu/publications/true-costs-food-system-reform-overviewtrue-cost-accounting-literature-and-initiatives.

Bebbington. J., Gray, R., Hibbitt, C., \& Kirk, E. (2001). Full Cost Accounting: An Agenda for Action. London: Certified Accountants Educational Trust.

Bebbington, J., Brown, J., \& Frame, B. (2007). Accounting technologies and sustainability assessment models. Ecological Economics, 61(2-3),224-236. doi:10.1016/j. ecolecon.2006.10.021.

Christ, K. L., \& Burritt, R. L. (2015). Material flow cost accounting: a review and agenda for future research. Journal of Cleaner Production, 108(B), 1378-1389. doi:10.1016/j. jclepro.2014.09.005.

Costanza, R., Hart, M., Posner, S., \& Talberth, J. (2009). Beyond GDP: The Need for New Measures of Progress. The Frederick S. Pardee Center for the Study of the LongerRange Future. Available at: https://pdxscholar.library.pdx.edu/cgi/viewcontent.cgi? article $=1010 \&$ context $=$ iss_pub.

Daly, H.E., \& Farley, J. (2010). Ecological Economics, Second Edition: Principles and Applications. Washington, DC: Island Press.

Elkington, J. (1999). Cannibals with Forks: The Triple Bottom Line of 21st Century Business. London: John Wiley \& Son.

Food and Agriculture Organization of the United Nations, International Fund for Agriculture Development, UNICEF, World Food Programme, \& World Health Organization (2019). The State of Food Security and Nutrition in the World 2019. Safeguarding Against Economic Slowdowns and Downturns. Rome: FAO. Available at: www. fao.org/3/ca5162en/ca5162en.pdf.

Hoozee, S., \& Hansen, S.C. (2018). A Comparison of Activity-Based Costing and Time-Driven Activity-Based Costing. Journal of Management Accounting Research, 30(1), 143-167. doi:10.2308/jmar-51686.

Howes, R. (2003). Environmental Cost Accounting: An Introduction and Practical Guide. Wokingham: CIMA Publishing.

Intergovernmental Panel on Climate Change. (2019). Climate Change and Land: an IPCC special report on climate change, desertification, land degradation, sustainable land management, food security, and greenhouse gas fluxes in terrestrial ecosystems [Summary for Policymakers].Available at: www.ipcc.ch/site/assets/uploads/sites/4/ 2020/02/SPM_Updated-Jan20.pdf.

Jasch, C. (2003). The use of Environmental Management Accounting (EMA) for identifying environmental costs. Journal of Cleaner Production, 11(6), 667-676. doi:10.1016/ S0959-6526(02)00107-5.

Jasinski, D., Meredith, J.O., \& Kirwan, K. (2015). A comprehensive review of full cost accounting methods and their applicability to the automotive industry. Journal of Cleaner Production, 108(A), 1123-1139. doi:10.1016/j.jclepro.2015.06.040. 
Kalender, Z.T. \& Vayvay, Ö. (2016). The Fifth Pillar of the Balanced Scorecard: Sustainability. Procedia - Social and Behavioral Sciences, 235, 76-83. doi:10.1016/j. sbspro.2016.11.027.

Kaplan, R.S. \& Norton, D.P. (1992). The Balanced Scorecard-Measures that Drive Performance. Harvard Business Review, (January-February 1992). Available at: https:// hbr.org/1992/01/the-balanced-scorecard-measures-that-drive-performance-2.

Krivokapić, Z. \& Jovanović, J. (2009). Using Balanced Scorecard to Improve Environmental Management System. Strojniški vestnik, Journal of Mechanical Engineering, 55(4), 262-271.

Lord, Steven. (2020). Valuing the impact of food: towards practical and comparable monetary valuation of food system impacts. A report of the Food System Impact Valuation Initiative (FoodSIVI). University of Oxford, Food System Transformation Group, Environmental Change Institute. United Kingdom. Available at: https://foodsivi.org/wpcontent/uploads/2020/06/Valuing-the-impact-of-food-Report_Foodsivi.pdf.

Madu, C.N. (2001). Environmental Cost Accounting and Business Strategy (pp. 119136). In Handbook of Environmentally Conscious Manufacturing.. New York, NY: Springer. doi:10.1007/978-1-4615-1727-6_6.

Millennium Ecosystem Assessment. (2005). Millennium Ecosystem Assessment Synthesis Report. Washington, DC: Island Press.

Pretty, J. (2003). Social Capital and the Collective Management of Resources. Science, 3029(5652), 1912-1914. doi:10.1126/science.1090847.

Putnam, R. (1993). The prosperous community: Social Capital and Public Life. The American Prospect, 13, 35-42.

Rockstrom, J., W. Steffen, K. Noone, A. Persson, F.S. Chapin, III, E. Lambin, T. M. Lenton, M. Scheffer, C. Folke, H. Schellnhuber, B. Nykvist, C.A. De Wit, T. Hughes, S. van der Leeuw, H. Rodhe, S. Sorlin, P.K. Snyder, R. Costanza, U. Svedin, M. Falkenmark, L. Karlberg, R.W. Corell, V.J. Fabry, J. Hansen, B. Walker, D. Liverman, K. Richardson, P. Crutzen, \& J. Foley. (2009). Planetary Boundaries: Exploring the Safe Operating Space for Humanity. Ecology and Society, 14(2), 32. Available at: www. ecologyandsociety.org/vol14/ iss 2/art32.

Sandhu, H., Nidumolu, U., \& Sandhu, S. (2012). Assessing Risks and Opportunities Arising from Ecosystem Change in Primary Industries Using Ecosystem Based Business Risk Analysis Tool. Human and Ecological Risk Assessment: An International Journal, 18(1), 47-68. doi:10.1080/10807039.2012.631469.

Sandhu, S. (2013). Towards an Integrated Conceptual Framework for Corporate Social and Environmental Sustainability. In Wells, G. (Ed.), Sustainable Business: Theory and Practice of Business Under Sustainability Principles (pp. 19-38). Cheltenham: Edward Elgar.

Sandhu, S., McKenzie, S., \& Harris, H. (Eds.) (2014). Linking Individual and Global Sustainability. Dordrecht: Springer Netherlands. doi:10.1007/978-994-017-9008-6.

Sandhu, H., Müller, A., Sukhdev, P., Merrigan, K., Tenkouano, A., Kumar, P., Hussain, S., Zhang, W., Pengue, W., Gemmill-Herren, B., Hamm, M.W., Tirado von der Pahlen, M.C., Obst, C., Sharma, K., Gundimeda, H., Markandya, A., May, P., Platais, G., \& Weigelt, J. (2019). The future of agriculture and food: Evaluating the holistic costs and benefits. The Anthropocene Review, 6(3), 270-278. doi:10.1177/ 2053019619872808.

Sandhu, H., Scialabba, N.E., Warner, C., Behzadnejad, F., Keohane, K., Houston, R., \& Fujiwara, D. (2020). Holistic costs and benefits of corn production systems in Minnesota, US. Scientific Reports, 10(3922), 1-12. doi:10.1038/s41598-020-60826-5. 
Smith, A. (1776). An Inquiry into the Nature and Causes of the Wealth of Nations. Chicago, IL: University of Chicago Press.

Soil \& More Impacts \& TMG Thinktank for Sustainability. (2020). True Cost Accounting: Inventory Report. Global Alliance for the Future of Food. Available at: https://futureoffood.org/wp-content/uploads/2020/07/TCA-Inventory-Report.pdf.

Sukhdev, P. (2018). Smarter metrics will help fix our food system. Nature, 558, 7. doi:10.1038/d41586-018-05328-1.

Sweetland, S.R. (1996). Human Capital Theory: Foundations of a Field of Inquiry. Review of Educational Research, 66(3), 341-359. https://doi.org/10.3102\%2F0034 6543066003341.

The Economics of Ecosystems and Biodiversity. (2018). TEEB for Agriculture \& Food: Scientific and Economic Foundations. UN Environment. Available at: http:// teebweb.org/agrifood/scientific-and-economic-foundations-report/.

United Nations. (1953). A System of National Accounts and Supporting Tables, Studies in Methods. United Nations Department of Economic Affairs, Statistical Office. Series F, No 2. Rev. 1. New York, NY: United Nations Publications.

United Nations. (2015). Transforming our world: the 2030 Agenda for sustainable development. Available at: www.un.org/ga/search/view_doc.asp?symbol=A/RES/ $70 / 1 \&$ Lang $=\mathrm{E}$.

United Nations, European Commission, Food and Agriculture Organization of the United Nations, Organisation for Economic Co-operation and Development, \& The World Bank. (2014). System of Environmental-Economic Accounting 2012-Experimental Ecosystem Accounting. Available at: https://unstats.un.org/unsd/envaccount ing/seearev/seea_cf_final_en.pdf.

United Nations University-International Human Dimensions Programme on Global Environmental Exchange and United Nations Environment Programme. (2014). Inclusive Wealth Report 2014. Cambridge: Cambridge University Press. 